\title{
EFFECT OF SPACING ON P AND Zn UPTAKE OF LOCAL T. AMAN RICE VARIETIES IN KHULNA AREA
}

\author{
S. Parvin ${ }^{1}$, M. M. Islam², M. K. Mondal ${ }^{3}$, K. G. Quddus ${ }^{2}$ and A. M. Mahmud ${ }^{4}$ \\ ${ }^{1}$ Lecturer, Agriculture Studies, Govt. Bangabandhu College, Rupsha, Khulna \\ ${ }^{2}$ Professor, Agrotechnology Discipline, Khulna University, Khulna \\ ${ }^{3}$ Collaborative Research Scientist, IRRI, Dhaka, Bangladesh \\ ${ }^{4}$ NGO Focal Person, DAK DIYE JAI \\ Corresponding author: parvin.shahanaz96@gmail.com
}

Key words: T. Aman, spacing, phosphorus, zinc

\begin{abstract}
A field experiment was conducted at the Agronomy field of Khulna University, Khulna during T. Aman season to evaluate the effects of spacing on nutrient content and total uptake of phosphorus and zinc by grain and straw of traditional rice of Khulna region. The experiment was laid out in split-plot design with three replications assigning three varieties viz., Jotai, Bashfulbalam, Ranisalute and three spacings viz., $30 \mathrm{~cm}$ x $30 \mathrm{~cm}, 40 \mathrm{~cm}$ x $40 \mathrm{~cm}$ and $50 \mathrm{~cm} \times 50 \mathrm{~cm}$. The variety was assigned in main plot and spacing in sub plot. The plot was fertilized with 40-50-35-5 $\mathrm{kg}$ of Urea-TSP-MOP and $\mathrm{ZnSO}_{4} \mathrm{ha}^{-1}$ respectively. The results indicated that the single effect of variety and spacing on $\mathrm{P}$ and $\mathrm{Zn}$ content in grain and straw varied significantly while the straw $\mathrm{P}$ content was found insignificant. The interaction effect of variety and spacing on $\mathrm{P}$ and $\mathrm{Zn}$ content was found significant in all the treatments. The highest $\mathrm{P}$ and $\mathrm{Zn}$ content of grain was found from the variety Ranisalute at $50 \mathrm{~cm} \times 50 \mathrm{~cm}\left(\mathrm{~V}_{3} \mathrm{~S}_{1}\right)$ but in straw from Ranisalute $\mathrm{x} 40$ $\mathrm{cm} \times 40 \mathrm{~cm}\left(\mathrm{~V}_{3} \mathrm{~S}_{2}\right)$ and Bashfulbalam $x 30 \mathrm{~cm} \times 30 \mathrm{~cm}\left(\mathrm{~V}_{2} \mathrm{~S}_{1}\right)$, respectively. The total uptake of $\mathrm{P}$ and $\mathrm{Zn}$ was found the highest from Jotai variety at $30 \mathrm{~cm}$ x $30 \mathrm{~cm}$ spacing. From the interaction it showed that the highest $\mathrm{P}$ and $\mathrm{Zn}$ uptake was found from Jotai $\mathrm{x} 30 \mathrm{~cm} \times 30 \mathrm{~cm}\left(\mathrm{~V}_{1} \mathrm{~S}_{1}\right)$ and the lowest from Ranisalute $x 50 \mathrm{~cm}$ x $50 \mathrm{~cm}\left(\mathrm{~V}_{3} \mathrm{~S}_{3}\right)$. The study indicated that though wider spacings of $40 \mathrm{~cm} \times 40 \mathrm{~cm}$ and $50 \mathrm{~cm} \times 50 \mathrm{~cm}$ increased the number of tillers hill ${ }^{-1}$ and nutrient uptake but it cannot increase the nutrient uptake and grain yield ha' ${ }^{-1}$. So, $30 \mathrm{~cm} \times 30 \mathrm{~cm}$ spacing showed positive relationship on nutrient uptake than $40 \mathrm{~cm} \mathrm{x} 40 \mathrm{~cm}$ and $50 \mathrm{~cm}$ x $50 \mathrm{~cm}$ spacing.
\end{abstract}

\section{Introduction}

Rice is the staple food of Bangladesh. It contributes about $90 \%$ of food grains and covers about $80 \%$ of total cropped area of the country. It provides about $70 \%$ of the calories consumed by 160 million people of Bangladesh (AIS, 2008). In order to increase the yield of rice plants the availability and uptake of proper and judicious use of fertilizers containing major and micronutrient is very important. The practice of intensive cropping with modern varieties causes a marked depletion of inherent nutrient reserve in soils of Bangladesh. Consequently in addition to N, P and K deficiencies, some other nutrient such as Zn, S and B deficiencies are being observed in many parts of the country (Haque and Jahiruddin, 1994).

Fertilizer is the most important input for rice production. For the best yield of rice plant along with nitrogen requirements, phosphorus and zinc is also needed. The application of $\mathrm{P}$ and $\mathrm{Zn}$ can play important role in grain setting, increased grain yield and nutrient concentration of rice. Phosphorus is important for the growth, reproduction, yield and quality of rice crop. Tillering of rice plant is positively co-related with Phosphorus. It also promotes root development and elongation capability of rice plant (Hossain et al., 2009).

Zinc deficiency has been detected as the third major nutritional problem for Bangladesh soil next to $\mathrm{N}$ and P limiting the growth of wetland rice. In some places of Bangladesh yield loss due to $\mathrm{Zn}$ deficiency 
Parvin et al.

ranged from $10-18 \%$. Zinc plays an important role in many physiological functions of plants. Planting densities exceed an optimum level competition among plants for macro and micro nutrients becomes severe consequently the plant growth stunted and grain yield decreases. The number of tillers per square meter is increased with the improvement of rice production (Islam, 2001). However, scanty information is available about the effect of spacing on the uptake of nutrients particularly $\mathrm{P}$ and $\mathrm{Zn}$ on rice. Therefore, the present study was conducted to find out the effect of spacing on the uptake and content of $\mathrm{P}$ and $\mathrm{Zn}$ of local T. Aman rice varieties of Khulna area.

\section{Materials and Methods}

The experiment was conducted in the field of Agro technology Discipline at Khulna University during T. Aman season. The soil was characterized by medium textured silty loam having $\mathrm{p}^{\mathrm{H}}$ value 7.5 and organic matter 3.80\%. Before raising seeds in the nursery, seeds were water soaked for 24 hours and these were kept in jute bags in dark conditions. After sprouting, the seeds were sown in wet seed bed. Thirty days old seedlings were uprooted carefully from the nursery and transplanted as single seedling hill $^{-1}$ on the well puddled experimental plots. Three popular $\mathrm{T}$. Aman rice varieties viz, jotai $\left(\mathrm{V}_{1}\right)$, Bashfulbalam $\left(\mathrm{V}_{2}\right)$ and Ranisalute $\left(\mathrm{V}_{3}\right)$ were selected for the study. The varieties were planted in three different spacings viz, 30 $\mathrm{cm} \times 30 \mathrm{~cm}\left(\mathrm{~S}_{1}\right), 40 \mathrm{~cm} \times 40 \mathrm{~cm}\left(\mathrm{~S}_{2}\right)$, and $50 \mathrm{~cm} \times 50 \mathrm{~cm}\left(\mathrm{~S}_{3}\right)$. The variety was assigned in main plot and spacing in sub plot. The plot size was $4.0 \mathrm{~m} \times 2.5 \mathrm{~m}$. The land was fertilized with 40-50-35-5 kg of ureaTSP-MoP- $\mathrm{ZnSO}_{4}$ ha $^{-1}$ respectively. The full dose of fertilizers and half of urea was applied as basal dose during final land preparation and the remaining half of urea was applied in two splits at active tillering and during panicle initiation stage. Grain yield and straw yield were recorded from whole plot basis leaving boarder lines. Grain yield was adjusted at $14 \%$ moisture content.

In order to conduct chemical analysis during harvest five representative samples of grain and straw from each sub plot were collected. The collected samples were analysed and Phosphorus (P) was determined by Spectrophotometer and Zinc (Zn) by atomic absorption spectrophotometer. The data was analyzed following standard statistical procedures (Gomez and Gomez, 1984) using a computer operated program MSTATC.

\section{Results and Discussion}

\section{P Concentration}

Phosphorus content in grain differed significantly due to the main effect of variety and spacing but it was found insignificant in straw (Table 1). It was ranged from $0.102 \%$ to $0.116 \%$ in grain and $0.030 \%$ to $0.032 \%$ in straw from the effect of varieties and $0.107 \%$ to $0.113 \%$ in grain and $0.028 \%$ to $0.032 \%$ in spacings. Among three varieties the maximum $\mathrm{P}$ content of grain $(0.116 \%)$ was found from Ranisalute variety which was followed by Bashfulbalm (0.115\%) and Jotai $(0.102 \%)$. The content of P was found samilar (0.113\%) in $50 \mathrm{~cm} \times 50 \mathrm{~cm}$ and $30 \mathrm{~cm} \times 30 \mathrm{~cm}$ spacing which was followed by $40 \mathrm{~cm} \times 40 \mathrm{~cm}$ spacing in straw $(0.107 \%)$. The grain content of $\mathrm{P}$ was higher compared to straw content of that in all treatments which supports the findings of Yoshida (1981) that contents of phosphorus (P) is generally higher in the panicles than in the straw (leaves and culm).

Table 1. Effect of variety and spacing on P and Zn content of grain and straw

\begin{tabular}{l|c|c|c|c}
\hline \multirow{2}{*}{ Treatments } & \multicolumn{2}{|c|}{$\mathrm{P}(\%)$} & \multicolumn{2}{c}{ Zn (ppm) } \\
\cline { 2 - 5 } & Grain & Straw & Grain & Straw \\
\hline $\mathrm{V}_{1}$ (Jotai) & 0.102 & 0.032 & 26.17 & 37.33 \\
$\mathrm{~V}_{2}$ (Bashfulbalam) & 0.115 & 0.031 & 36.94 & 40.17 \\
$\mathrm{~V}_{3}$ (Ranisalute) & 0.116 & 0.030 & 37.61 & 34.28
\end{tabular}


Spacing Effect on P and Zn Content of Local T. Aman Rice Varieties

\begin{tabular}{lcccc} 
Level of Significance & 0.01 & NS & 0.01 & 0.01 \\
$\operatorname{LSD}_{(0.01)}$ & 0.06899 & - & 1.220 & 2.821 \\
$\mathrm{~S}_{1}(30 \mathrm{~cm} \times 30 \mathrm{~cm})$ & 0.113 & 0.032 & 32.11 & 39.50 \\
$\mathrm{~S}_{2}(40 \mathrm{~cm} \times 40 \mathrm{~cm})$ & 0.107 & 0.032 & 32.72 & 37.44 \\
$\mathrm{~S}_{3}(50 \mathrm{~cm} \times 50 \mathrm{~cm})$ & 0.113 & 0.028 & 35.89 & 34.83 \\
Level of Significance & 0.05 & $\mathrm{NS}$ & 0.01 & 0.01 \\
\hline $\mathrm{LSD}(0.01)$ & 0.06899 & - & 1.220 & 2.821 \\
$\mathrm{CV}(\%)$ & 7.00 & 24.51 & 1.67 & 3.47 \\
\hline
\end{tabular}

Interaction effect of variety $\mathrm{x}$ spacing was found statistically significant in both grain and straw (Table 2). It was ranged from $0.095 \%$ to $0.0128 \%$ in grain and $0.025 \%$ to $0.037 \%$ in straw. The highest grain content $(0.128 \%)$ was found from $\mathrm{V}_{3} \mathrm{~S}_{3}$ and the lowest $(0.095 \%)$ from Jotai x $30 \mathrm{~cm}$ x $30 \mathrm{~cm}\left(\mathrm{~V}_{1} \mathrm{~S}_{1}\right)$. In straw the highest $\mathrm{P}$ content $(0.037 \%)$ was found from Ranisalute x $40 \mathrm{~cm}$ x $40 \mathrm{~cm}\left(\mathrm{~V}_{3} \mathrm{~S}_{2}\right)$ and the lowest $(0.025 \%)$ from both Ranisalute x $50 \mathrm{~cm}$ x $50 \mathrm{~cm}\left(\mathrm{~V}_{3} \mathrm{~S}_{3}\right)$ and Bashfulbalam x $40 \mathrm{~cm}$ x $40 \mathrm{~cm}\left(\mathrm{~V}_{2} \mathrm{~S}_{2}\right)$.

\section{Zn concentration}

Zn concentration in grain and straw was significantly affected by the main effect of variety and spacing. Among three varieties the grain $\mathrm{Zn}$ content was found the maximum (37.61 ppm) from jotai which was followed by Bashfulbalam (36.94 ppm) and Ranisalute (26.17 ppm). But in straw Zn content was found the highest (40.17 ppm) from Bashfulbalam and the lowest (34.28 ppm) from Ranisalute. The highest $\mathrm{Zn}$ content $(35.89 \mathrm{ppm})$ was found from $50 \mathrm{~cm} \times 50 \mathrm{~cm}$ and the lowest $(26.17 \mathrm{ppm})$ from $30 \mathrm{~cm} \mathrm{x} 30 \mathrm{~cm}$ spacing. In straw the highest Zn content (37.44 ppm) was found from $40 \mathrm{~cm} \mathrm{x} 40 \mathrm{~cm}$ and the lowest (34.83 ppm) from $50 \mathrm{~cm}$ x $50 \mathrm{~cm}$ spacing (Table 2). Interaction effect of variety x spacing was found statistically significant in both grain and straw Zn content ranged from $24.67 \mathrm{ppm}$ to $41.00 \mathrm{ppm}$ in grain and $32.00 \mathrm{ppm}$ to $43.33 \mathrm{ppm}$ in straw (Table 2). The highest $(41.00 \mathrm{ppm})$ and the lowest (24.67 ppm) $\mathrm{Zn}$ content in grain was obtained from Ranisalute x $50 \mathrm{~cm} \mathrm{x} 50 \mathrm{~cm}\left(\mathrm{~V}_{3} \mathrm{~S}_{3}\right)$ and Jotai x 30 $\mathrm{cm} \times 30 \mathrm{~cm}\left(\mathrm{~V}_{1} \mathrm{~S}_{1}\right)$, respectively. The straw content of $\mathrm{Zn}$ was higher compared to grain content that confirms the findings of Yoshida (1981). The highest (43.33 ppm) and the lowest (32.00 ppm) straw Zn content was obtained from Bashfulbalam x $30 \mathrm{~cm}$ x $30 \mathrm{~cm}\left(\mathrm{~V}_{2} \mathrm{~S}_{1}\right)$ and Ranisalute x $50 \mathrm{~cm}$ x $50 \mathrm{~cm}\left(\mathrm{~V}_{3} \mathrm{~S}_{3}\right)$, respectively.

\section{Phosphorus uptake}

The interaction effect of variety $\mathrm{x}$ spacing on $\mathrm{P}$ uptake was shown in figure 1,3 and 5 . It was observed that variety Jotai uptake the highest P than Bashfulbalam and Ranisalute (Fig. 1, 3 and 5). The spacing 30 $\mathrm{cm} \times 30 \mathrm{~cm}$ uptake the highest $\mathrm{P}$ than $40 \mathrm{~cm} \times 40 \mathrm{~cm}$ and $50 \mathrm{~cm} \times 50 \mathrm{~cm}$. Though wider spacing enhanced nutrient uptake but the highest grain yield was obtained from $30 \mathrm{~cm}$ x $30 \mathrm{~cm}$ spacing as a result the total uptake of P was obtained from $30 \mathrm{~cm}$ x $30 \mathrm{~cm}$ spacing. Actually wider spacing promoted more tillering than lower spacing but tiller number per square meter is important for total uptake of nutrient than tillers hill ${ }^{-1}$ (Islam, 2001). The interaction of Jotai x $30 \mathrm{~cm}$ x $30 \mathrm{~cm}\left(\mathrm{~V}_{1} \mathrm{~S}_{1}\right)$ uptake the highest $\mathrm{P}$ $\left(4.85 \mathrm{~kg} \mathrm{ha}^{-1}\right)$ and the lowest $\left(3.0 \mathrm{~kg} \mathrm{ha}^{-1}\right)$ was found from Ranisalute x $50 \mathrm{~cm} \mathrm{x} 50 \mathrm{~cm}\left(\mathrm{~V}_{3} \mathrm{~S}_{3}\right)$ interactions.

Table 2. Effect of variety x spacing interaction on $\mathrm{P}$ and $\mathrm{Zn}$ content of grain and straw

\begin{tabular}{l|cccc}
\hline \multirow{2}{*}{ Interaction (Variety x Spacing) } & \multicolumn{2}{|c|}{$\mathrm{P}(\%)$} & \multicolumn{2}{c}{ Zn (ppm) } \\
\cline { 2 - 5 } & Grain & Straw & Grain & Straw \\
\hline $\mathrm{V}_{1} \mathrm{~S}_{1}$ & 0.108 & 0.32 & 24.67 & 42.17 \\
$\mathrm{~V}_{1} \mathrm{~S}_{2}$ & 0.102 & 0.35 & 26.83 & 35.17 \\
$\mathrm{~V}_{1} \mathrm{~S}_{3}$ & 0.950 & 0.28 & 27.00 & 34.67 \\
$\mathrm{~V}_{2} \mathrm{~S}_{1}$ & 0.115 & 0.35 & 36.83 & 43.33 \\
$\mathrm{~V}_{2} \mathrm{~S}_{2}$ & 0.115 & 0.25 & 34.33 & 39.33 \\
$\mathrm{~V}_{2} \mathrm{~S}_{3}$ & 0.115 & 0.32 & 39.67 & 37.83 \\
$\mathrm{~V}_{3} \mathrm{~S}_{1}$ & 0.115 & 0.28 & 34.83 & 33.00
\end{tabular}


Parvin et al.

\begin{tabular}{lcccc}
$\mathrm{V}_{3} \mathrm{~S}_{2}$ & 0.103 & 0.37 & 37.00 & 37.83 \\
$\mathrm{~V}_{3} \mathrm{~S}_{3}$ & 0.128 & 0.25 & 41.00 & 32.00 \\
\hline $\mathrm{LSD}_{(0.01)}$ & 0.07 & $\mathrm{NS}$ & 1.22 & 2.82 \\
$\mathrm{CV}(\%)$ & 7.00 & 24.51 & 1.67 & 3.47 \\
\hline
\end{tabular}

$\mathrm{V}_{1}$ = Jotai, $\mathrm{V}_{2}=$ Bashfulbalam, $\mathrm{V}_{3}=$ Ranisalute

$\mathrm{S}_{1}=30 \mathrm{~cm} \times 30 \mathrm{~cm}, \mathrm{~S}_{2}=40 \mathrm{~cm} \times 40 \mathrm{~cm}, \mathrm{~S}_{3}=50 \mathrm{~cm} \times 50 \mathrm{~cm}$

\section{Zinc Uptake}

The interaction effect of variety x spacing on Zn uptake was shown in figure 2, 4 and 6. It was observed that variety Jotai uptake the highest Zn than Bashfulbalam and Ranisalute (Fig. 2, 4 and 6). The spacing $30 \mathrm{~cm}$ x $30 \mathrm{~cm}$ uptake the highest Zn than $40 \mathrm{~cm}$ x $40 \mathrm{~cm}$ and $50 \mathrm{~cm}$ x $50 \mathrm{~cm}$. Though wider spacing enhanced nutrient uptake but the highest yield was obtained from $30 \mathrm{~cm}$ x $30 \mathrm{~cm}$ spacing. The interaction of Jotai x $30 \mathrm{~cm}$ x $30 \mathrm{~cm}\left(\mathrm{~V}_{1} \mathrm{~S}_{1}\right)$ uptake the highest $\mathrm{Zn}\left(0.273 \mathrm{~kg} \mathrm{ha}^{-1}\right)$ and the lowest $\left(0.156 \mathrm{~kg} \mathrm{ha}^{-1}\right)$ was found from Ranisalute x $50 \mathrm{~cm}$ x $50 \mathrm{~cm}\left(\mathrm{~V}_{3} \mathrm{~S}_{3}\right)$.

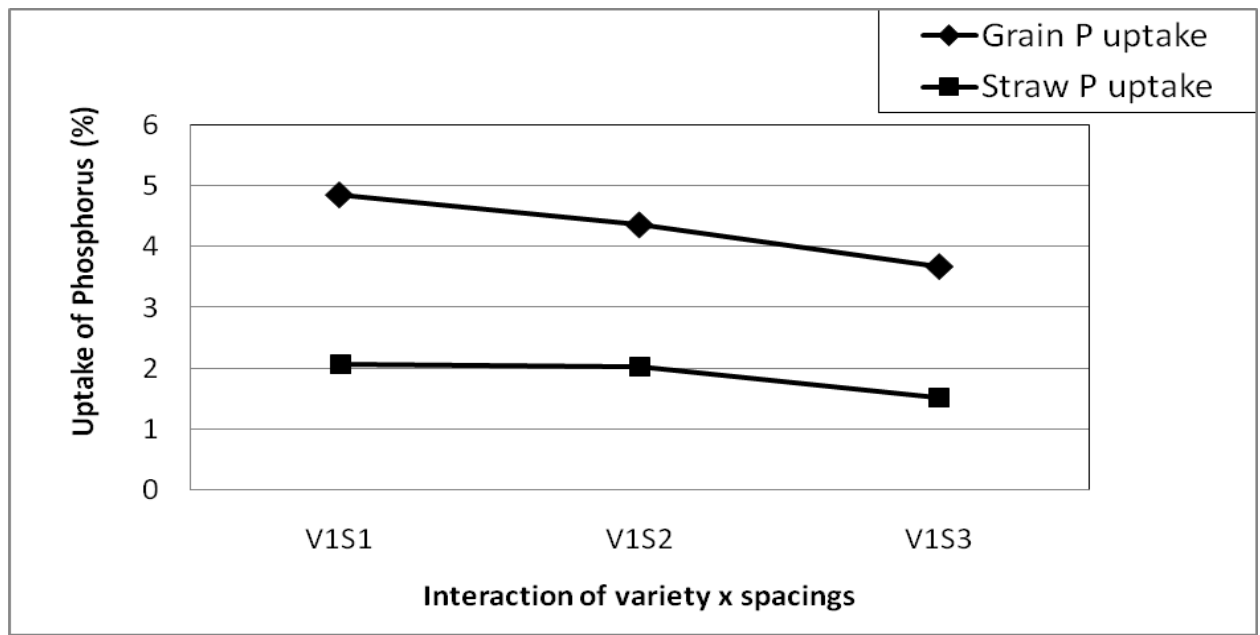

Fig. 1. Phosphorus uptake by Jotai variety in three spacings



Fig. 2. Zinc uptake by Jotai variety in three spacings 
Spacing Effect on P and Zn Content of Local T. Aman Rice Varieties

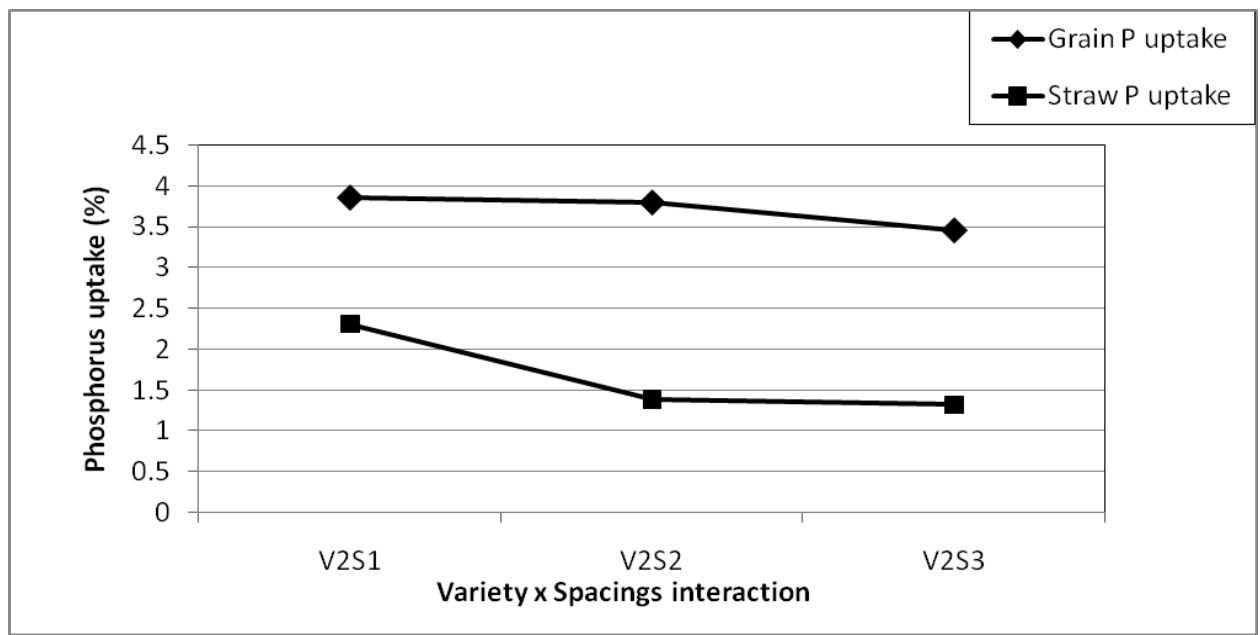

Fig. 3. Phosphorus uptake by Bashfulbalam variety in three spacing

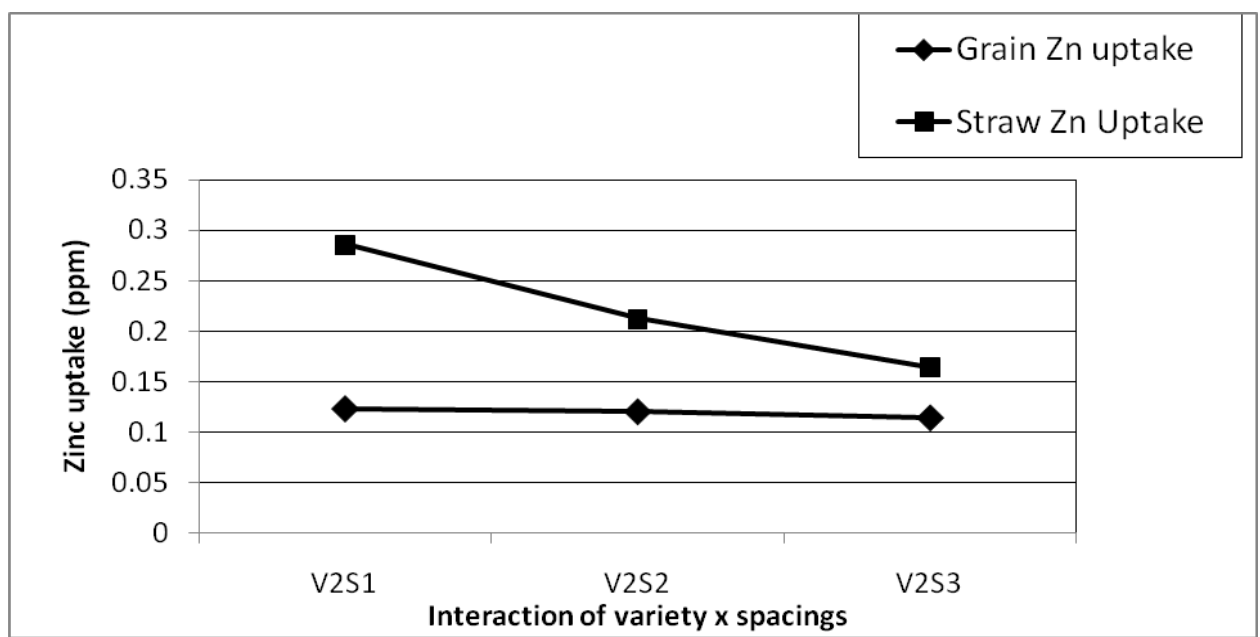

Fig. 4. Zinc uptake by Bashfulbalam variety in three spacing

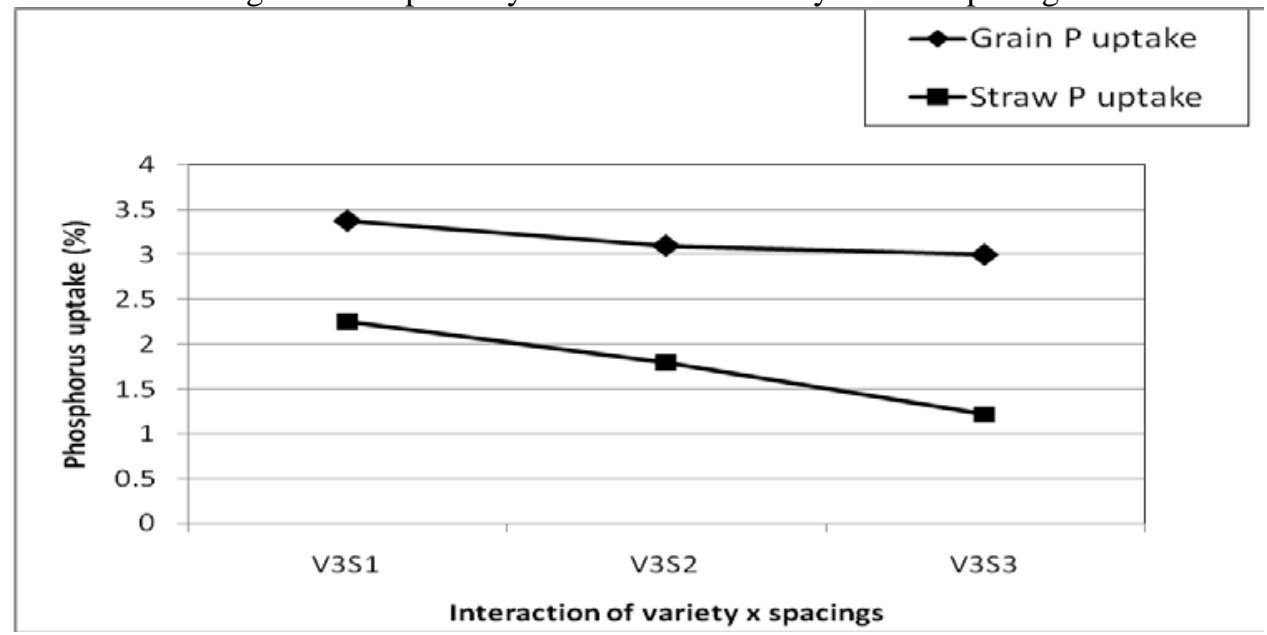

Fig. 5. Phosphorus uptake by Ranisalute variety in three spacing 
Parvin et al.

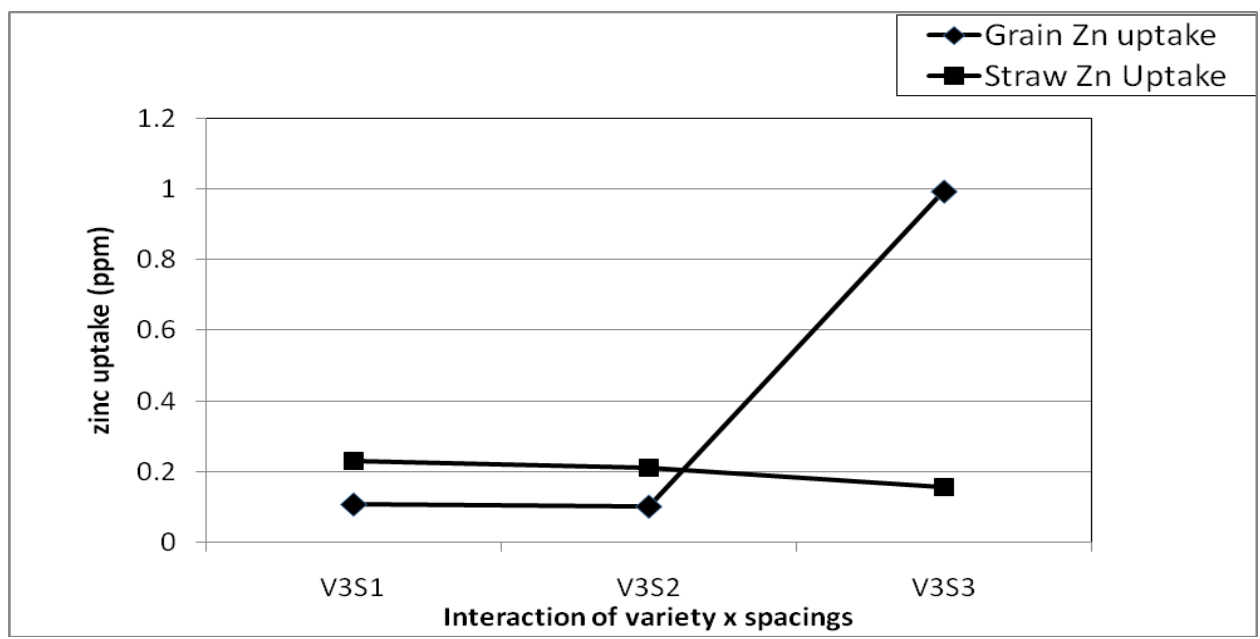

Fig. 6. Zinc uptake by Ranisalute variety in three spacing

\section{Nutrient status of soil}

Nutrient status of the experimental soil before planting and after harvest was shown in Table 3 . Before planting the nutrient N, P, K, Zn and S content of soil was $0.207 \%, 7.15$ ppm, 0.36 meq. $100 \mathrm{~g}^{-1}$ soil, 0.46 ppm and 129.53 ppm, respectively. After harvest the N, P, K, Zn and S content of soil were $0.250 \%, 4.17$ ppm, $0.27 \mathrm{~m} . e q / 100 \mathrm{~g}$ soil, $0.883 \mathrm{ppm}$ and $218.38 \mathrm{ppm}$, respectively. Recovery of $\mathrm{P}$ and $\mathrm{Zn}$ was obtained from basal application of $50 \mathrm{~kg} \mathrm{P}_{2} \mathrm{O}_{5} \mathrm{ha}^{-1}$ and $30 \mathrm{~kg} \mathrm{ZnSO}_{4} \mathrm{ha}^{-1}$. In the experimental plot the deficiency of $\mathrm{P}$ and $\mathrm{Zn}$ was present before planting and different level of $\mathrm{P}$ and $\mathrm{Zn}$ fertilizer was not applied in the treatment that's why apparent recovery of these two nutrients was smaller than field experiments. The results indicated that added elements ( $\mathrm{P}$ and $\mathrm{Zn}$ ) might have residual effect on the succeeding crop (Jahiruddin et al., 1994).

Table 3. Some important properties of the experimental soils

\begin{tabular}{l|l|l}
\hline Parameters & Before planting & After harvest \\
\hline Texture & Silty Loam & Silty Loam \\
$\mathrm{P}^{\mathrm{H}}$ & 7.5 & 7.6 \\
E.C & $7.77 \mathrm{ds} \mathrm{m}^{-1}$ & $8.87 \mathrm{ds} \mathrm{m}^{-1}$ \\
Organic matter & $3.80 \%$ & $5.17 \%$ \\
Total N & $0.207 \%$ & $0.25 \%$ \\
Exchangeable K & 0.36 meq. $100 \mathrm{~g}^{-1}$ soil & 0.27 meq. $100 \mathrm{~g}^{-1}$ soil \\
Exchangeable Ca & 27.50 meq. $100 \mathrm{~g}^{-1}$ soil & 38.17 meq. $100 \mathrm{~g}^{-1}$ soil \\
Exchangeable Mg & 5.75 meq. $100 \mathrm{~g}^{-1}$ soil & 7.78 meq. $100 \mathrm{~g}^{-1}$ soil \\
Available P & 7.15 ppm & $4.17 \mathrm{ppm}$ \\
Total Zn & $0.46 \mathrm{ppm}$ & $0.883 \mathrm{ppm}$ \\
Available S & $129.53 \mathrm{ppm}$ & $218.38 \mathrm{ppm}$ \\
\hline
\end{tabular}


Spacing Effect on P and Zn Content of Local T. Aman Rice Varieties

The overall results of the present study showed that the single and interaction effect of variety and spacing showed significant influence on phosphorus and zinc content in grain and straw but the straw phosphorus content was insignificant from the single effect of variety and spacing. The uptake of phosphorus and zinc was found the highest in closer spacing than wider spacing. The number of tillers square meter ${ }^{-1}$ was more in closer spacing $30 \mathrm{~cm}$ x $30 \mathrm{~cm}$ than wider spacing $40 \mathrm{~cm} \mathrm{x} 40 \mathrm{~cm}$ and $50 \mathrm{~cm} \mathrm{x}$ $50 \mathrm{~cm}$. So, it can be the concluded that the uptake of nutrient depends on number of tillers square meter $^{-1}$ than number of tillers hill ${ }^{-1}$.

\section{References}

AIS (Agricultural Information Service). 2008. Krishi Dairy. Agric. Int. Ser. Dhaka. pp.20-22.

BRRI (Bangladesh Rice Research Institute). 1989. Annual Internal Review for 1989. Bangladesh Rice Res. Inst. Gazipur-1701. pp.169-171.

Gomez, K. A. and A. A. Gomez. 1984. Statistical procedures for Agricultural Research. Intl. Rice Res. Inst. Los Banos, Laguna, Philippines. pp.97-116.

Haque, M. S. and M. Jahirruddin. 1994. Effect of single and multiple application of sulphur and zinc in a continuous rice cropping pattern. Indian J. Agric. Res. 28(1): 9-14.

Hossain, M. B., M. Jahiruddin, M. R. H. Loppert, G. M. Panaullah, M. R. Islam and J. M. Duxbury. 2009. The effects of iron plaque and phosphorus on yield and arsenic accumulation in rice. J. Plant Soil. 317: 167-176.

Islam, M. 2001. Enhancement of and yield of Boro rice through modification of SRI (System of Rice Intensification) technique in terms of fertilizer management, spacing and seedling age. M. Sc. Thesis, Dept. of Agronomy. BAU, Mymensingh.

Jahiruddin, M., M. N. Islam, M. A. Hashem and M. R. Islam. 1994. Influence of Sulphur, Zinc and Boron on yield and nutrient uptake of BR2 rice. Progress. Agric. 59(1): 61-67.

Rahman, K. M. M., M. A. K. Chowdhury, F. Sharmeen, A. Sarkar, M. A. Hye and G. C. Biswas. 2011. Effect of zinc and phosphorus on yield of Oryza sativa (cv.BR-11). Bangladesh Res. Pub. J. 4 (5): 351-358.

Yoshida, S. 1981. Fundamentals of Rice Crop Science. The Intl. Rice Res. Inst. Los Banos, Laguna, Philippines. 